\title{
Great doctors in English literature: Sir Roderick Glossop
}

\author{
P M J BENNETT
}

The eminent brain specialist, Sir Roderick Glossop, of $6 \mathrm{~b}$ Harley Street and Ditteredge Hall, Hants, bestrode the world of P G Wodehouse like a colossus: not least because he was one of the very few characters to have a foot in both the Wooster/ Jeeves canon and the Blandings Castle sagas. Sir Roderick's practice encompassed many of the ancient, noble, and barmy families in the kingdom; unfortunately, from the point of view of medical research, his appearances in the narratives are occasioned by episodes such as his daughter Honoria's mercifully brief engagements to Bertie Wooster and his friends, so we have few glimpses of Sir Roderick at work.

One of the reasons why he moved with such ease among the aristocracy was that he was born to it, and he had been at school with Clarence, 9th Earl of Emsworth, who recalled him as "a most unpleasant boy with a nasty, superior manner and an extraordinary number of spots on his face." It was Lord Emsworth's recollection of Sir Roderick by his school nickname, "Pimples," which so affronted the celebrated alienist that he refused to visit Blandings to assess the sanity of the egg throwing Duke of Dunstable.

Presumably at some stage he lost his pimples and acquired the unmistakable appearance of his prime. "He had a pair of shaggy eyebrows which gave his eyes a piercing look which was not at all the sort of thing a fellow wanted to encounter on an empty stomach. He was fairly tall and fairly broad and he had the most enormous head, with practically no hair on it, which made it seem bigger and much more like the dome of St Paul's. I suppose he must have taken about a nine, or something, in hats. Shows what a rotten thing it is to let your brain develop too much."

That was Bertie Wooster's description of him at the luncheon arranged by Aunt Agatha for Sir Roderick to meet his prospective son in law. Bertie had accidentally become engaged to Honoria after his botched (not devised by Jeeves) scheme to promote Bingo Little's suit for her hand. Honoria was truly her father's daughter, "one of those robust girls with the muscles of a welterweight and a laugh like a squadron of cavalry charging over a tin bridge." Unpardonably she wished to be rid of Jeeves after her marriage. This led directly to his revelation of the three cats and the fish, earlier deposited in Bertie's bedroom by his cousins, Claud and Eustace. Sir Roderick concluded that Bertie was insane, an opinion which persisted for several further years.

The luncheon itself had been a pretty stiff occasion as Sir Roderick was, at the time, president of the west London branch of the anti-gambling league, drank no wine, strongly disapproved of smoking, and could eat only the simplest food owing to an impaired digestion. In later years this austere outlook seems to have been considerably mellowed by the constant social round.

Wooster himself had anticipated Sir Roderick's attitude, and his unspoken thoughts paint a vivid picture of Sir Roderick's clinical method: "He was . . . always called a nerve specialist because it sounds better-but everybody knows that he's really a sort of janitor to the loony-bin ... he toddles round, gives the patient the once-over, talks about 'over-excited nervous systems' and recommends complete rest and seclusion, and all that sort of thing. Practically every posh family has called him in at one

The Health Centre, West Byfleet, Weybridge, Surrey

P M J BENNETT, MB, BCHIR, general practitioner

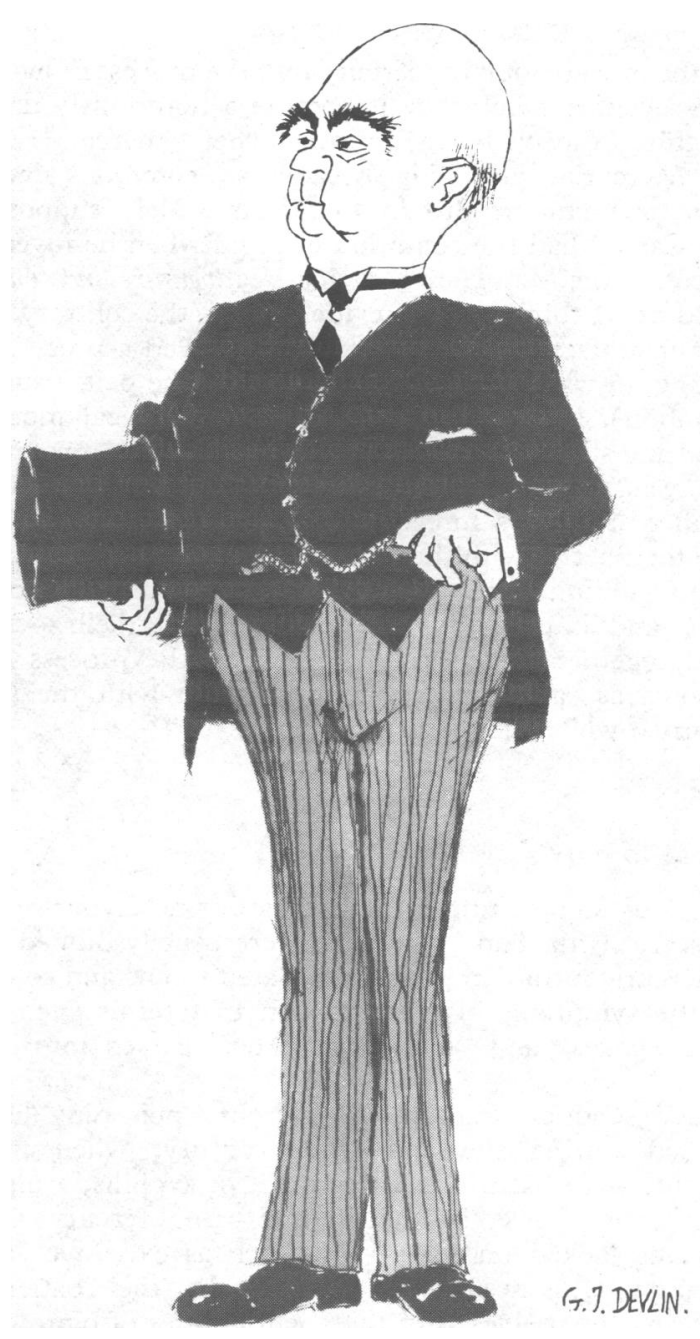

time or another and I suppose that being in that position-I mean constantly having to sit on people's heads while their nearest and dearest 'phone to the asylum to send round the wagon-does tend to make a chappie take, what you might call, a warped view of humanity."

Sir Roderick's first wife was a Miss Blatherwick. Her sister, who had "the aspect of one who had had bad news about the year 1900 and had never really got over it," was married to Professor Pringle of Cambridge ... "a thinnish, baldish, dyspeptic-lookingish cove, with an eye like a haddock." Bertie gallantly undertook to take his chum Oliver Randolph Sipperley's place on a visit to the Pringles. Here he nearly gets engaged to Sir Roderick's niece Eloise, who, in a most ghastly way, resembled her cousin Honoria; both had "a voice like a liontamer, making some authoritative announcement to the troupe." Fortunately, Sir Roderick arrived on a visit and denounced Bertie's imposture, snorting violently: "he ought to be under proper restraint. It is abominable that a person in his mental condition should be permitted to roam the world at large. The next stage may quite easily be homicidal."

Sir Roderick's repute was such that, in mid-career, his practice even extended across the Atlantic to New York, where he was called to attend $\mathrm{Mr}$ George Stoker, whose behaviour varied between the extremely eccentric and the totally potty; he disliked all his near relations and left his $\$ 50$ million fortune 
to his cousin, Mr J Washburn Stoker. Lest any of those relatives dispute the will, J Washburn relied on Sir Roderick ". . . to testify that the late $\mathrm{Mr}$ Stoker, while possibly somewhat individual in his habits, was nevertheless perfectly sane. The testimony of so eminent a medical specialist as Sir Roderick would be unassailable."

Largely as a result of this warm relationship, Sir Roderick was relying on $\mathrm{J}$ Washburn to realise his ambition to purchase Chufnell Hall, Chufnell Regis, Somerset, to run as a sort of country club for his nerve patients. At the same time Sir Roderick, now widowed, had become engaged to Myrtle, the Dowager Lady Chufnell. It was her stepson, the 5th Baron Chufnell, who rented a cottage on his estate to Bertie, exiled from his London apartments by his devotion to playing the banjolele. This new hobby had even caused a total rift with Jeeves, who promptly entered the service of Lord Chufnell. Lady Chufnell in the course of a previous marriage had had a son, Seabury, a peculiarly revolting infant given to demanding protection money. It is he, Seabury, who insists on Sir Roderick's blacking up to perform minstrel songs at the piano as we are told that "he has a pleasing baritone voice and, as a younger man, in the days when he was a medical student, was often accustomed to render songs at smoking concerts and similar entertainments."

Seabury, however, unsuccessful in his endeavour to extract protection money, prepared a butter slide booby trap for Sir Roderick. He, immediately after coming a stinker on this, subjected Master Seabury to a severe castigation, whereupon "the affection which Her Ladyship felt for Sir Roderick was instantaneously swept away on the tidal wave of injured motherlove," and the engagement was off. Sir Roderick then stormed out of the house and encountered Bertie, also blacked up for different reasons .... and it is from this point onwards that the rapprochement between the two begins. Bertie reflects: "the more I thought of this stripling, the more the iron entered my soul, and one result of my meditations regarding him was to engender, I think it's 'engender,' an emotion towards Sir Roderick Glossop which came pretty near to being a spirit of kindliness . . . nobody, I reasoned, who could slosh young Seabury like that could be altogether bad."

But Sir Roderick's misfortunes continued as, later that night while still blacked up, he was arrested by Constable Dobson while apparently making burglarious entry to Bertie Wooster's garage and was locked in the potting shed: meanwhile, $\mathrm{J}$ Washburn Stoker has received a cablegram stating that his relatives are contesting cousin George's will. Emitting a mirthless laugh, he says: "Yes, the joke's certainly on me. I staked everything on the evidence of this man Glossop: I rely on him to save my fifty-million by testifying that old George wasn't loco and two minutes after I've put him on the stand the other side'll come right back at me by showing that my expert is a loony himself, loonier than ever George could've been if he'd tried for a thousand years."

The problem: how to extract Sir Roderick from the potting shed under the nose of the constabulary to preserve his reputation unsullied? Jeeves's solution: distract PC Dobson with a message to meet Mary (parlourmaid) in the raspberry bushes, then substitute Bertram Wooster for Sir Roderick; and all ends happily. Bertie is rewarded for his self sacrifice with the heartiest of breakfasts: J Washburn does purchase the Hall for Sir Roderick from young Lord Chufnell, who does become engaged to J Washburn's daughter Pauline. It turns out that Sir Roderick does not have to "testify that old George was Grade A in the sanity line" as the cablegram about the contested will turns out to be another Jeeves masterstroke of misinformation. Amid this feast of reconciliation, one morsel is lacking; Sir Roderick does not immediately resume his engagement to Myrtle, Lady Chufnell. It is clear that his experience of young Seabury as a prospective stepson quite overrode his romantic passion.

The next well documented incident in Sir Roderick's life concerns his visit to Blandings Castle, Market Blandings, Shropshire. In fact the real Sir Roderick does not personally visit Blandings, but is impersonated in so doing by Frederick Altamont Cornwallis Twistleton, 5th Earl of Ickenham, Pongo Twistleton-Twistleton's Uncle Fred. Blandings castle, in its long history, had impostors as other dwellings have mice. Uncle Fred and Pongo had already set off from Paddington station in the guise of the celebrated nerve specialist and his secretary, when they encountered the real Sir Roderick on the train, as he had been persuaded to change his mind about the trip. Lord Ickenham, quite unperturbed, began to prattle genially: "Well, Glossop, it's extraordinary nice seeing you again. . . . You're going to Blandings Castle now, no doubt, to inspect some well-connected screwball ?"

Sir Roderick pursed his lips: "You are asking me to betray confidences, I fear. . . . However, I may perhaps gratify your curiosity to the extent of saying that my visit is a professional one. A friend of the family has been giving evidence of an over-excited nervous condition."

"There's no need to be coy with me, Glossop. You're going to Blandings to put ice on the head of a chap with an eggthrowing urge."

Uncle Fred told Sir Roderick that he could, after all, save himself a journey as the patient was travelling on the same train. Sir Roderick then engaged this man in conversation and satisfied himself that the patient was quite sane, with no indication of any egg fixation. Accordingly, he got off the train at Oxford and returned to London, not, however, without casting his professional eye at young Pongo's discomfiture during their encounter.

Some years later Bertie is taking tea on the lawn at Brinkley Court when the butler hove to: "Well, when I say 'butler' I use the term loosely. He was dressed like a butler and he behaved like a butler, but in the deepest and truest sense of the word he was not a butler. Reading from left to right he was Sir Roderick Glossop." It seems entirely fitting that the culmination of Sir Roderick's career should find him adopting the persona of Swordfish, the butler. Butlers, as a class, are the closest approximation, in terms of dignity and sagacity, to the supreme Jeeves.

Sir Roderick had been recruited incognito by Aunt Dahlia 
to observe the behaviour of Wilbert Cream, the notorious New York playboy, who is thought to have stolen the celebrated cow-creamer.

Sir Roderick, even when clothed with the magic mantle of butlerdom, is quite unable to unravel the amazing imbroglio which ensues at Brinkley. Fortunately, Jeeves returns to the scene, refreshed after his shrimping holiday at Herne Bay, rapidly resolving everybody's problem and placating the Creams by suggesting to them that Sir Roderick was masquerading as a butler in order to observe Bertie Wooster's behaviour.

Although nearly all the recorded evidence about Sir Roderick's career is concerned with his relationship with Bertram Wooster, fortunately, the archive contains this revealing exchange: "I wish I had a brain like yours,' said Lord Ickenham, 'What an amazing thing; I suppose you can walk down a line of people, giving each of them a quick glance, and separate the sheep from the goats like shelling peas ... "loony ... not loony ... this one wants watching ....this one's all right . . . keep an eye on this chap, don't let him get near the breadknife." Extraordinary! What do you do, exactly? Start topics and observe reactions?'

" 'Yes. I suppose you might say-broadly-that that is the method I employ'."

On such a foundation was not only a giant individual reputation laid but also the mighty edifice of modern psychiatric practice.

\title{
"O that I were young again": Yeats and the Steinach operation
}

\author{
STEPHEN LOCK
}

How can I, that girl standing there, My attention fix

On Roman or on Russian

Or on Spanish politics?...

And maybe what they say is true

Of war and war's alarms

But $O$ that I were young again

And held her in my arms!

In late middle age W B Yeats passed through a phase of gloom and inactivity. Suddenly he took on a new lease of life, embarking on fresh activities and producing the superb poems of his last years. The cause of this change, I would suggest, whether physical or psychological, was a "rejuvenation" operation-the Steinach procedure which Yeats underwent in the spring of 1934.

Without the effects of this operation we may ask certain questions. Would Yeats have become such close friends with Margot Ruddock, a young poet, actress, and dancer, who came on to the scene some six months after the operation? To make a more tentative suggestion, a year later would he have taken on such vigorous new friendships, as with Lady Dorothy Wellesley and Ethel Mannin, or fresh projects, such as the BBC readings of his poetry accompanied by a fiddle or a drum ? Would he, also a year after the operation, have had the audacity to make such a bizarre selection of poems for the Oxford Book of Modern Verse -which excluded some of the poets of the first world war, such as Wilfred Owen, as well as some of the best work of the new school of Auden, Day-Lewis, and Spender-not to mention also leaving out distinguished contemporary Irish poets, such as Austin Clarke. ${ }^{1}$ And, finally, would we have had those marvellous poems of the last few years-when he said "lust and rage" were dancing attendance on him ?

We shall never know the definitive answers to any of these questions, but it is worth examining the circumstances. The idea of surgical operations aimed at restoring sexual potency or at rejuvenation goes back at least to Claude Bernard. He established that glands could be classified into the exocrine and the

British Medical Journal London WC1H 9JR

STEPHEN LOCK, MB, FRCP, editor

Based on a talk given on 6 May 1983 at Thor Ballylee, Yeats's country house, to the section of the history of medicine of the Royal Academy of Medicine in Ireland. endocrine varieties, ${ }^{2}$ and it was his successor in the chair at Paris, Charles Brown-Séquard, who put theory into practice. By giving himself regular injections of an aqueous extract of guinea pig testes, Brown-Séquard claimed that at the age of 72 he felt 30 years younger. In the famous lecture in which he announced this Brown-Séquard said that that morning he had paid a visit to Mme Brown-Séquard, the phrase in French, "faire une visite," having a double entendre. ${ }^{3}$

The public reacted to Brown-Séquard's claims with enthusiasm-there was little doubt that such injections did have some effects but they proved to be transitory; and, after a few years, the work was largely forgotten. Even so, at about the same time that Brown-Séquard was making his initial claims in Paris, a young Austrian physiologist was starting research into the physiology of animal gonads.

This physiologist was Eugen Steinach, born in 1861, who had worked in both Innsbruck and Prague before he was appointed professor of physiology at the University of Vienna in 1912.4 Working with rats, Steinach came to three conclusions. Firstly, that the testis contained both exocrine and endocrine elements; secondly, that castration diminished the sex characteristics and that these reappeared once the testes were implanted again; and, thirdly, that old rats who were given a testicular implant from young rats underwent rejuvenation: they showed a general improvement but particularly an "insatiable" interest in sexual activity.

\section{Steinach operation}

Finally, Steinach found that it was the endocrine cells of the graft which survived, and hypertrophied, and that the same effect could be produced without a transplant by increasing the blood flow to the animal's own testis. This could be done by ligating the vas deferens, and, to see whether there would be any effect in human subjects, Steinach asked a Viennese surgeon, Karl Lichtenstern, to try the operation out.

The first operation for rejuvenation was carried out in 1918 and its effects are well described in Steinach's own book. ${ }^{5}$

"The patient was a man who was not aged in years but who was particularly suitable as an object lesson in the effects of vasoligature because his general condition presented a typical picture of premature senility without organic disease. $\mathrm{He}$ was a perfect example of presenile exhaustion. 